Received: 2017.12.21 Accepted: 2018.02.05 Published: 2018.04.30

\title{
Clinical Benefit from Tyrosine Kinase Inhibitors in Metastatic Merkel Cell Carcinoma: A Case Series of 5 Patients
}

Authors' Contribution: Study Design A Data Collection B Statistical Analysis C Data Interpretation D Manuscript Preparation E Literature Search F Funds Collection G
ABCDEF 1 Erica S. Tarabadkar

ABDEF 1 Hannah Thomas

ABCDE 2 Astrid Blom

CDE 3 Upendra Parvathaneni

BCDEF 4 Thomas Olencki

ABCDEFG 1 Paul Nghiem

ABCDEFG 5 Shailender Bhatia
1 Department of Internal Medicine/Division of Dermatology, University of Washington, Seattle, WA, U.S.A.

2 Department of Dermatology, Hôpital Ambroise Paré, Boulogne-Billancourt, France 3 Department of Radiation Oncology, University of Washington, Seattle, WA, U.S.A.

4 Department of Internal Medicine/Division of Medical Oncology, The Ohio State University, Columbus, OH, U.S.A.

5 Department of Internal Medicine/Division of Medical Oncology, University of Washington, Seattle, WA, U.S.A.
Corresponding Author: Conflict of interest:

Source of suppport:

Shailender Bhatia, e-mail: sbhatia@uw.edu

Paul Nghiem: Paid consultant (EMD-Serono); Shailender Bhatia: Advisory board (Genentech; EMD-Serono); Research support (EMDSerono, BMS, Merck, Oncosec, Immune Design, NantKwest)

Supported by NIH grants K24-CA139052, R01-CA162522, R01-CA176841, ARCS Fellowship, the David \& Rosalind Bloom Endowment for MCC Research, the Michael Piepkorn Endowment Fund, MCC patient gift fund, NIH K24 CA-139052, and the Monica Yolles Fund

\begin{abstract}
Case series
Patients:

Final Diagnosis:

Symptoms:

Medication:

Clinical Procedure:

Specialty:

Objective:

Background:

Case Report:

Male, $58 \cdot$ Male, $65 \bullet$ Male, $75 \bullet$ Male, $61 \bullet$ Male, 69

Merkel cell carcinoma

Metastatic disease

Pazopanib • Cabozantinib

Systemic therapy

Oncology

\section{Rare disease}

Merkel cell carcinoma (MCC) is a rare but aggressive neuroendocrine skin cancer. The estimated 5-year survival of patients with metastatic disease is approximately $14 \%$. Cytotoxic chemotherapy is associated with a modest median progression-free survival (PFS) of only 3 months. In recent studies, immunotherapy with anti-PD-1/anti-PD-L1 antibodies has demonstrated a high response rate in immunocompetent patients $(>50 \%$ in chemotherapy-naïve patients) and responses are typically durable. However, approximately $50 \%$ of immunocompetent patients do not respond to immunotherapy. In addition, immunosuppressed patients have limited therapeutic options. Hence, there is a significant unmet need for effective treatments in these subpopulations. We describe 5 patients (out of 24 total) with metastatic MCC who were treated with a vascular endothelial growth factor receptor (VEGFR) tyrosine kinase inhibitor (TKI), either pazopanib $(n=4)$ or cabozantinib $(n=1)$, with clinical benefit. One patient had a complete response to pazopanib after 3 months of therapy. Four patients had stabilization of disease that lasted from 5 months to 3.5 years. In an immunosuppressed patient with psoriatic arthritis, stabilization of MCC was also associated with improvement in his arthritis that allowed cessation of immunosuppression. Patients did not develop any unusual toxicities from VEGFR-TKIs.

Conclusions: Treatment with VEGFR-TKIs demonstrated clinical benefit in this selected small group of patients with metastatic MCC. Prospective investigation of VEGFR-TKIs is warranted in this population, especially in patients with disease refractory to immunotherapy.
\end{abstract}

MeSH Keywords: Carcinoma, Merkel Cell • Immunotherapy • Programmed Cell Death 1 Receptor • Receptors, Vascular Endothelial Growth Factor

Full-text PDF: https://www.amjcaserep.com/abstract/index/idArt/908649

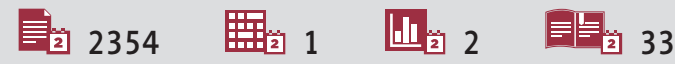




\section{Background}

Merkel cell carcinoma (MCC) is a rare but aggressive neuroendocrine skin carcinoma with an annual incidence of approximately 2500 cases in the United States, which is increasing [1-3]. Eighty percent of MCC tumors are associated with the Merkel cell polyomavirus (MCPyV) [4]. Staging is predictive of survival, with 5 -year overall survival for local, nodal, and distant disease at $51 \%, 35 \%$, and $14 \%$, respectively [5].

In patients with distant metastatic disease, the median survival from the time of initial metastasis is approximately 10 months [6]. Metastatic MCC is generally treated with cytotoxic chemotherapy, commonly with platinum-based agents plus etoposide, as first-line therapy. Although cytotoxic chemotherapy has a high ( $>50 \%$ ) objective response rate (ORR), responses are seldom durable; the median progression-free survival (PFS) is a modest 94 days [7-9]. The response rate for secondline cytotoxic chemotherapy is much lower (23\%), with a median PFS of only 61 days [9].

Recent prospective clinical trials have demonstrated promising efficacy of programmed death 1 (PD-1) and programmed death ligand 1 (PD-L1) inhibitors in advanced MCC. In the firstline setting, ORRs for pembrolizumab, avelumab, and nivolumab were $56 \%$ (14/26 patients) [10], 62\% (24/39) [11], and 73\% $(11 / 15)$ [12], respectively. In the chemotherapy-refractory setting, avelumab had an ORR of $31.8 \%$ (28/88 patients) [13]. Responses were strikingly durable in these trials. However, a considerable proportion of patients with metastatic MCC do not respond to PD-1/PD-L1 blockade. Many patients are not candidates for immunotherapy due to autoimmune or immunosuppressive comorbid conditions. Hence, there is still an unmet need for other therapeutic options in this disease.
While the rationale for immunotherapy in MCC has been well described, there has been little success in identifying tumor-signaling pathways amenable to molecular targeting in MCC [14]. There is increasing evidence supporting the importance of angiogenesis in the pathogenesis of MCC. Cutaneous MCC tumors frequently have a characteristic appearance suggestive of increased vascularity (Figure 1). There is evidence of prominent vascular proliferation in up to $20 \%$ of MCC tumors, which appears to be a shared feature across many neuroendocrine tumors [15]. MCC tumors have expression of vascular endothelial growth factor (VEGF)-A, VEGF-C, VEGF-R2, and plateletderived growth factor (PDGF)-b in $91 \%, 75 \%, 88 \%$, and $72 \%$ of tumors, respectively [16]. Up to $80-90 \%$ of MCC tumors express platelet-derived growth factor receptor (PDGFR)-A [17,18]. MCC tumors have also been shown to express c-kit [19-22]. One study showed a positive correlation between tumor size and vascular endothelial growth factor receptor (VEGFR)-2 expression, with $91 \%$ of tumors $\geq 2.0 \mathrm{~cm}$ expressing VEGFR- 2 vs. $70 \%$ of tumors $<2.0 \mathrm{~cm}[23]$. This evidence supports the potential utility of anti-angiogenic drugs in this aggressive disease.

Pazopanib and cabozantinib are inhibitors of multiple receptor tyrosine kinases, (VEGFR)-1, -2 , and -3 and Kit. Pazopanib also inhibits (PDGFR)- $\alpha$ and $-\beta$. There is minimal published clinical data on their utility in MCC. A single case report demonstrated 6 months of clinical benefit from pazopanib in a patient with metastatic MCC after treatment with multiple rounds of chemotherapy [24]. There was a mutation in PDGFR- $\alpha$ gene and expression of VEGF, giving a possible explanation for the response [24]. To add to this literature, we describe a case series of successful use of VEGFR-tyrosine kinase inhibitors (TKIs) in 5 patients with metastatic MCC (Table 1). These patients were selected from a total of 24 patients with metastatic MCC who were treated with TKIs standardly (i.e., not on an investigational protocol) due to lack of other treatment

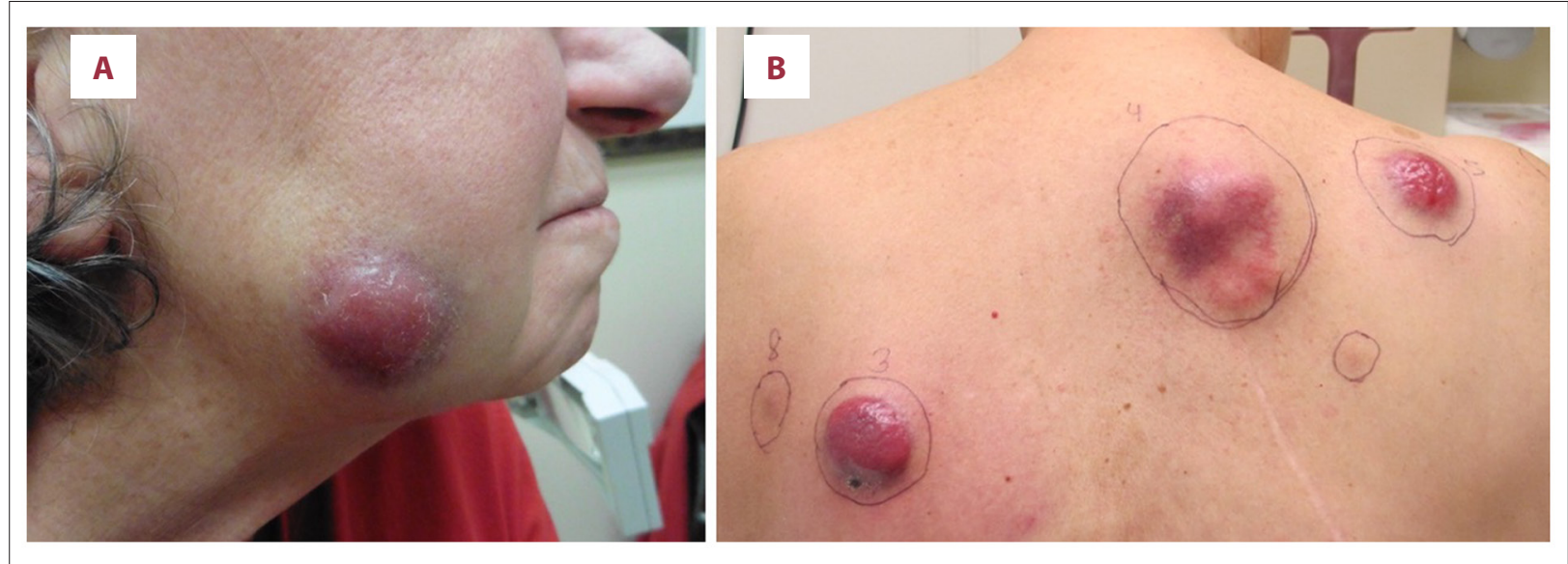

Figure 1. Panel A and B show large cutaneous MCC tumors on 2 separate patients. MCC tumors generally have a characteristic appearance suggestive of increased vascularity, supporting the importance of angiogenesis in these tumors. (These 2 patients are not included in this case series.) 
Table 1. Patient characteristics, treatment, and response to TKIs.

\begin{tabular}{|c|c|c|c|c|c|c|c|c|c|}
\hline Patient & $\begin{array}{l}\text { Age, y/ } \\
\text { Sex }\end{array}$ & $\begin{array}{c}\text { Stage } \\
\text { at MCC } \\
\text { diagnosis* }\end{array}$ & $\begin{array}{l}\text { Time from } \\
\text { diagnosis of } \\
\text { metastatic } \\
\text { disease to } \\
\text { TKI therapy }\end{array}$ & $\begin{array}{l}\text { Therapies for } \\
\text { metastatic } \\
\text { disease } \\
\text { prior to TKI } \\
\text { therapy }\end{array}$ & $\begin{array}{l}\text { Sites of } \\
\text { metastases at } \\
\text { the time of TKI } \\
\text { therapy }\end{array}$ & $\begin{array}{l}\text { TKI used } \\
\text { and dose }\end{array}$ & $\begin{array}{l}\text { Duration } \\
\text { of clinical } \\
\text { benefit } \\
\text { from TKI }\end{array}$ & $\begin{array}{l}\text { Treatment } \\
\text { after TKI }\end{array}$ & Comments \\
\hline 1 & $58 / M$ & IV & 2 months & $\begin{array}{l}\text { Single } \\
\text { fraction RT }\end{array}$ & $\begin{array}{l}\text { Popliteal, } \\
\text { inguinal, } \\
\text { periaortic, } \\
\text { retroperitoneal } \\
\text { LNs, liver, } \\
\text { cutaneous }\end{array}$ & $\begin{array}{l}\text { Pazopanib } \\
800 \text { mg/d }\end{array}$ & 5 months & $\begin{array}{l}\text { Combination } \\
\text { Pazopanib and } \\
\text { Octreotide, } \\
\text { Carboplatin } \\
\text { plus Etoposide }\end{array}$ & $\begin{array}{l}\text { Improvement } \\
\text { of psoriatic } \\
\text { arthritis on } \\
\text { TKI }\end{array}$ \\
\hline 2 & $65 / M$ & $\begin{array}{l}\text { IV, } \\
\text { unknown } \\
\text { primary }\end{array}$ & 10 months & $\begin{array}{l}\text { Carboplatin } \\
\text { plus } \\
\text { etoposide, } \\
\text { RT }\end{array}$ & $\begin{array}{l}\text { Right } \\
\text { paratracheal, } \\
\text { right hilum, } \\
\text { prevascular, } \\
\text { sub carinal } \\
\text { LNs }\end{array}$ & $\begin{array}{l}\text { Pazopanib } \\
800 \mathrm{mg} / \mathrm{d} \text {, } \\
\text { hepatic } \\
\text { toxicity, } \\
\text { improved } \\
\text { with dose } \\
\text { reduction to } \\
400 \mathrm{mg} / \mathrm{d} \text {, } \\
\text { increased to } \\
600 \mathrm{mg} / \mathrm{d}\end{array}$ & $\begin{array}{l}14 \\
\text { months }\end{array}$ & $\begin{array}{l}\text { Single fraction } \\
\text { RT, Octreotide }\end{array}$ & $\begin{array}{l}\text { Stabilization } \\
\text { of disease for } \\
\text { additional } 10 \\
\text { months on } \\
\text { Octreotide }\end{array}$ \\
\hline 3 & $75 / M$ & IIB & 10 months & $\begin{array}{l}\text { Topotecan, } \\
\text { craniotomy } \\
\text { and RT to } \\
\text { brain }\end{array}$ & $\begin{array}{l}\text { Cervical, b/l } \\
\text { axillary, left } \\
\text { subpectoral, } \\
\text { retroperitoneal, } \\
\text { external } \\
\text { iliac and b/l } \\
\text { inguinal LNs }\end{array}$ & $\begin{array}{l}\text { Pazopanib } \\
800 \text { mg/d }\end{array}$ & 7 months & $\begin{array}{l}\text { Combination } \\
\text { Pazopanib and } \\
\text { Octreotide }\end{array}$ & $\begin{array}{l}\text { Stabilization } \\
\text { of progressive } \\
\text { disease for } \\
\text { an additional } \\
16 \text { months on } \\
\text { combination } \\
\text { Pazopanib and } \\
\text { Octreotide }\end{array}$ \\
\hline 4 & $61 / M$ & IV & 6 months & $\begin{array}{l}\text { Carboplatin } \\
\text { plus } \\
\text { Etoposide, } \\
\text { Topotecan, } \\
\text { single } \\
\text { fraction RT }\end{array}$ & $\begin{array}{l}\text { Abdominal and } \\
\text { retroperitoneal } \\
\text { LNs, pancreas } \\
\text { and spleen }\end{array}$ & $\begin{array}{l}\text { Pazopanib } \\
800 \mathrm{mg} / \mathrm{d} \text {, } \\
\text { decreased to } \\
400 \mathrm{mg} / \mathrm{d}\end{array}$ & 7 months & $\begin{array}{l}\text { Single } \\
\text { fraction RT, } \\
\text { Pembrolizumab }\end{array}$ & $\begin{array}{l}\text { PFS longer } \\
\text { on pazopanib } \\
\text { than prior } \\
\text { chemotherapy }\end{array}$ \\
\hline 5 & $69 / M$ & $\begin{array}{l}\text { IV, } \\
\text { unknown } \\
\text { primary }\end{array}$ & 6 months & $\begin{array}{l}\text { Cisplatin } \\
\text { plus } \\
\text { Etoposide }\end{array}$ & $\begin{array}{l}\text { Retroperitoneal } \\
\text { LN }\end{array}$ & $\begin{array}{l}\text { Cabozantinib, } \\
60 \mathrm{mg} / \mathrm{d} \\
\text { dose reduced } \\
\text { to } 40 \mathrm{mg} 5 \\
\text { days/week }\end{array}$ & 3.5 years & $\begin{array}{l}\text { Nivolumab } \\
\text { RT }\end{array}$ & $\begin{array}{l}\text { TKI therapy } \\
\text { allowed } \\
\text { bridging to } \\
\text { immunotherapy }\end{array}$ \\
\hline
\end{tabular}

* American Joint Committee on cancer (AJCC) staging system $7^{\text {th }}$ edition. TKI - tyrosine kinase inhibitors; MCC - Merkel cell carcinoma; M - Male: y - year; Gy - gray; RT - radiation therapy; LN - lymph nodes; d - daily; b/l - bilateral, PFS - progression free survival.

options. We have selected these 5 cases to highlight the potential utility of these agents in different clinical scenarios. All studies were performed in accordance with Helsinki principles and were approved by the Institutional Review Board at the Fred Hutchinson Cancer Research Center (IRB \#6585). All patients included in this study had provided informed consent for their clinical data to be analyzed for research purposes.

\section{Case Reports}

\section{Patient 1}

A 58-year-old man presented with a left calf primary MCC tumor and lower-extremity edema. A staging FDG PET-CT scan revealed widely disseminated $M C C$ involving multiple (popliteal, inguinal, periaortic, and retroperitoneal) lymph nodes, cutaneous metastases, and liver metastases. He had a history of severe, symptomatic psoriatic arthritis, which had required 


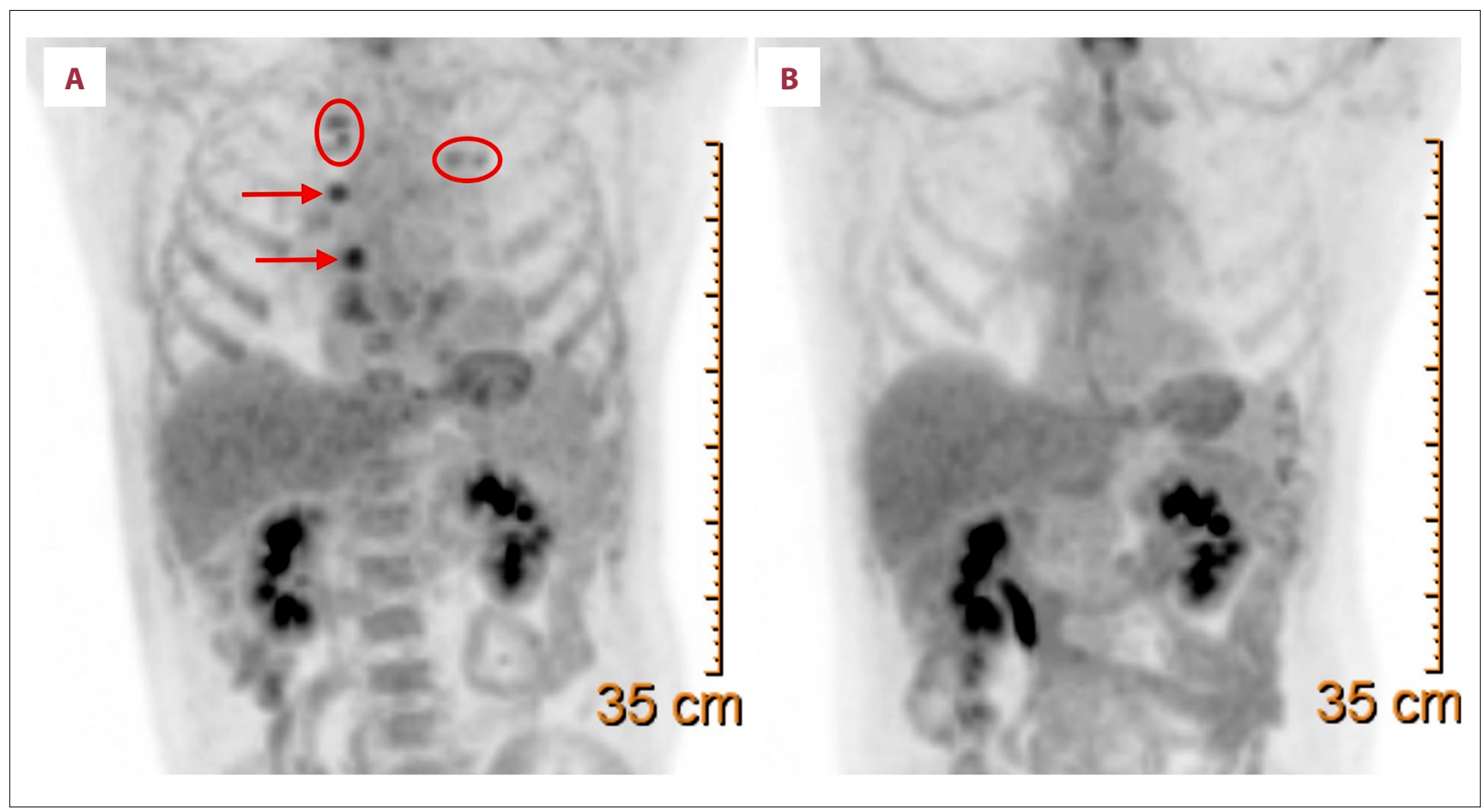

Figure 2. Panel A represents hypermetabolic paratracheal, subcarinal, hilar, and mediastinal lymph nodes (circles and arrows) in patient \#2 prior to initiation of pazopanib. Panel B represents a complete metabolic response of the FDG-avid lymph nodes in the chest after 3 months of therapy with pazopanib.

treatment with several systemic immunosuppressive drugs, including methotrexate, efalizumab, etanercept, and adalimumab over the past 3 years. He received single-fraction high-dose ( 8 Gray) radiation therapy to the bulky inguinal and retroperitoneal lymph nodes, with rapid palliation of his lower-extremity edema. He received pazopanib $800 \mathrm{mg}$ daily and noticed regression of cutaneous metastases within 2 weeks of starting therapy. Restaging FDG PET-CT scan 2 weeks after starting pazopanib showed interval improvement of hypermetabolic metastatic sites. He also had marked improvement in his arthritis and was able to discontinue systemic immunosuppression throughout the duration of pazopanib therapy. He continued to receive pazopanib for 5 months, before he developed disease progression at nodal sites for which he was treated with combination pazopanib and octreotide for 3 months. He developed metastases in the pancreas and died weeks later despite receiving carboplatin plus etoposide.

\section{Patient 2}

A 65-year-old man presented with syncopal episodes related to compression of the superior vena cava from extensive and bulky (up to $10 \mathrm{~cm}$ in size) lymphadenopathy involving supraclavicular, mediastinal, and paratracheal lymph nodes. A biopsy of the left supraclavicular lymph node revealed MCC with no evidence of a primary cutaneous tumor. He initially received 6 cycles of carboplatin plus etoposide and concurrent radiation therapy (36 Gy) to mediastinal and supraclavicular lymph nodes, with initial regression of all tumors. Three months after the last cycle of chemotherapy, he had progressive disease at several new lymph nodes in the chest. He received pazopanib $800 \mathrm{mg}$ daily and developed hepatic toxicity, which improved with dose reduction to $400 \mathrm{mg}$ daily and did not recur with subsequent cautious dose escalation to $600 \mathrm{mg}$ daily. Three months after starting pazopanib, a restaging FDG PETCT scan showed complete resolution of previously FDG-avid lymph nodes in the chest (right hilar, right paratracheal, mediastinal, prevascular, and subcarinal lymph nodes, Figure 2). He received pazopanib for 14 months before developing significant progressive disease in abdominal and retroperitoneal lymph nodes. He then received treatment with single-fraction high-dose radiation and depot octreotide acetate injections for 10 months before dying due to obstructive jaundice from pancreatic metastases.

\section{Patient 3}

A 75-year-old man was diagnosed with MCC of the right posterior scalp, which was treated with wide excision. Shortly after the excision, he developed recurrent disease with enlarged right cervical and supraclavicular lymph nodes. He received 4 cycles of carboplatin plus etoposide chemotherapy and concurrent radiation therapy to the primary tumor bed (60 Gy) and right neck (64 Gy), with a complete response to therapy. Thirteen months later, he developed progressive disease in cervical and inguinal lymph nodes. He received 6 cycles of 
topotecan, with a mixed response. A restaging PET-CT at 3 months after topotecan ended revealed progressive disease in cervical, bilateral axillary, subpectoral, retroperitoneal, iliac, and inguinal lymph nodes. He also developed a metastatic lesion in the right frontal lobe of the brain, treated with surgery and radiation. He then received pazopanib $800 \mathrm{mg}$ daily. Four months after therapy, a restaging PET-CT revealed decreased FDG avidity at known sites of disease. Three months later, mild progression of disease was noted on restaging scans. An OctreoScan suggested somatostatin receptor expression on MCC tumors, and once-monthly depot octreotide acetate injections were administered concurrently with pazopanib. He tolerated this combination and continued treatment for another 16 months before he died due to progressive disease.

\section{Patient 4}

A 61-year-old man presented with a primary MCC tumor on the right lower back and extensive metastatic disease involving the pancreas, multiple intra-abdominal soft tissue masses, and a $9-\mathrm{cm}$ tumor in the splenic hilum. He was treated with carboplatin plus etoposide chemotherapy, with an initial response after 2 cycles of therapy. He developed progressive disease after the 4th cycle of chemotherapy. He then received 2 cycles of topotecan, but a restaging PET-CT scan revealed significant progression of tumors. He received single-fraction high-dose (6-8 Gy) radiation therapy (RT) to some of the bulky metastatic sites, followed by initiation of pazopanib $800 \mathrm{mg} /$ day 1 month after RT. Restaging scans 2 and 4 months after initiation of pazopanib revealed decreased avidity and size of various metastatic sites without any new lesions. He was progres sion-free for a total of 7 months after initiation of pazopanib, before he developed progressive disease and died. The PFS of 7 months with pazopanib was longer than the progression-free interval with first- and second-line chemotherapy regimens.

\section{Patient 5}

A 69-year-old man presented with an enlarged left supraclavicular lymph node, and biopsy revealed MCC. Staging PET-CT showed mediastinal, retroperitoneal, and pelvic lymphadenopathy. Biopsy of a left periaortic lymph node and right supraclavicular lymph node confirmed metastatic MCC. A primary cutaneous tumor was not identified. He received 5 cycles of chemotherapy (cisplatin plus etoposide) with an initial partial response. Four months after starting chemotherapy, progression was noted in retroperitoneal lymph nodes. He initially received cabozantinib, $60 \mathrm{mg}$ daily. This dose was decreased to $40 \mathrm{mg} 5$ days a week due to diarrhea, abdominal cramping, and hypertension. He received cabozantinib for 21 months total before it was stopped due to development of muscle weakness in the lower extremities, with concern for rhabdomyolysis. The symptoms were attributed to spinal stenosis. Despite discontinuation of cabozantinib, he remained progression-free for approximately 3.5 years after starting cabozantinib, before he developed recurrence in the left supraclavicular lymph node. $\mathrm{He}$ is currently receiving treatment with nivolumab and $\mathrm{RT}$, with an encouraging initial clinical response. The prolonged disease control associated with cabozantinib has enabled bridging to immunotherapy, which was not available for MCC treatment at the time of his initial presentation.

\section{Discussion}

In this case series, we describe the successful use of VEGFRTKIs, pazopanib and cabozantinib, in 5 patients with metastatic MCC. These patients, who had previously received cytotoxic chemotherapy and did not have access to immunotherapy trials, experienced prolonged disease control for several months, with good tolerability. This report highlights the possibility of clinical benefit with VEGFR TKIs in this aggressive cancer.

There are many limitations to this report. These 5 cases were selected from a total of 24 patients treated with VEGRF-TKIs, because of successful clinical outcomes. Therefore, this case series represents a biased portrayal of TKI efficacy and should not be used to estimate the proportion of metastatic MCC patients who could benefit from this approach. This case series is only meant to suggest potential clinical scenarios that could benefit from the use of these drugs in MCC. Efficacy of these agents needs to be studied with prospective clinical trials. Our experience suggests that clinical benefit from these agents should include stable disease as a meaningful endpoint, in addition to objective responses, because several patients in this series had prolonged stabilization of disease without an objective response as defined by RECIST. Since the proportion of patients deriving clinical benefit is unlikely to be high, correlative studies must incorporate exploration of predictive biomarkers to help patient selection. In this series, we were unable to study MCC tumor expression or activating mutations in c-kit or PDGFR to correlate with clinical benefit.

There are prospective clinical trials already underway that are investigating these agents. A single-arm multicenter phase 2 clinical trial in the UK (clinicaltrialsregister.eu; Eudra CT\# 2011003226-27) is investigating pazopanib in patients with metastatic MCC. Preliminary results from 16 evaluable patients include a partial response rate of $19 \%$ ( $3 / 16$ patients) and a disease control rate (objective response plus stable disease for $>12$ weeks) of $56 \%(9 / 16)$ [25]. Another trial is investigating cabozantinib (clinicaltrials.gov; NCT02036476) at a single center in the US.

In our series, the duration of benefit from pazopanib was longer than that observed with prior chemotherapy regimens in those patients who had received chemotherapy. The use of 
pazopanib was associated with improved arthritic symptoms in patient \#1 and allowed discontinuation of immune suppression. Angiogenic mechanisms are relevant in pathophysiology of inflammatory arthritis, and the anti-angiogenic effects of VEGFR-TKIs may be beneficial in these patients with MCC [26]. Typically, immunosuppressed patients with MCC have dismal outcomes [27], and the discontinuation of immune suppression in arthritic patients could potentially improve MCC outcomes. The duration of clinical benefit from VEGFR-TKIs can be used as a bridge towards standard or investigational immunotherapy by stabilizing the disease. Unlike cytotoxic chemotherapy, anti-angiogenic therapy is not thought to be immune-suppressive. These agents may improve the efficacy of immunotherapy by modulating the tumor microenvironment through reduction of immune suppressive cytokines and regulatory $T$ cells $[28,29]$.

MCC, a neuroendocrine cancer, commonly expresses somatostatin receptors [30]. In 2 patients (\#2 and \#3), the duration of benefit from VEGFR-TKIs was prolonged by addition of longacting octreotide agents in patients whose tumors expressed somatostatin receptors. Patient \#3 received pazopanib in combination with octreotide acetate, with stabilization of disease for an additional 16 months. The favorable toxicity profile of VEGFR-TKIs and somatostatin analogues supports the safety of combining the 2 modalities. Two patients (\#1 and \#4) received single-fraction high-dose radiation to bulky tumors for disease stabilization prior to starting pazopanib. Single-fraction high-dose radiation can be used for debulking large or symptomatic tumors prior to initiation of TKIs [31]. Complications have been reported with the concurrent use of radiotherapy

\section{References:}

1. Albores-Saavedra J, Batich K, Chable-Montero F et al: Merkel cell carcinoma demographics, morphology, and survival based on 3870 cases: A population based study. J Cutan Pathol, 2010; 37: 20-27

2. Fitzgerald TL, Dennis S, Kachare SD et al: Dramatic increase in the incidence and mortality from merkel cell carcinoma in the United States. Am Surg, 2015; 81: 802-6

3. Paulson KG, Park SY, Vandeven NA et al: Merkel cell carcinoma: Current united states incidence and projected increases based on changing demographics. J Am Acad Dermatol 2017 [Epub ahead of print]

4. Feng $\mathrm{H}$, Shuda M, Chang Y, Moore PS: Clonal integration of a polyomavirus in human Merkel cell carcinoma. Science, 2008; 319: 1096-100

5. Harms KL, Healy MA, Nghiem P et al: Analysis of prognostic factors from 9387 Merkel cell carcinoma cases forms the basis for the new $8^{\text {th }}$ edition AJCC Staging System. Ann Surg Oncol, 2016; 23: 3564-71

6. Miller NJ, Bhatia S, Parvathaneni U et al: Emerging and mechanism-based therapies for recurrent or metastatic Merkel cell carcinoma. Curr Treat Options Oncol, 2013; 14: 249-63

7. Tai PT, Yu E, Winquist $\mathrm{E}$ et al: Chemotherapy in neuroendocrine/Merkel cell carcinoma of the skin: case series and review of 204 cases. J Clin Oncol, 2000; 18: 2493-99

8. Voog E, Biron P, Martin JP, Blay JY: Chemotherapy for patients with locally advanced or metastatic Merkel cell carcinoma. Cancer, 1999; 85: 2589-95

9. Iyer JG, Blom A, Doumani R et al: Response rates and durability of chemotherapy among 62 patients with metastatic Merkel cell carcinoma. Cancer Med, 2016; 5: 2294-301 with VEGF-TKIs; hence, we recommend caution with the timing of TKIs around RT [32,33].

\section{Conclusions}

In summary, this retrospective case series highlights the potential utility of VEGFR-TKIs in MCC patients. Given the modest benefit with cytotoxic chemotherapy in advanced MCC, VEGFR-TKIs may provide clinical benefit in patients who progressed after PD-1 blockade and/or who were not eligible for the same. Further data from prospective clinical trials are needed to determine the efficacy of TKIs as monotherapy and in combination with immunotherapy.

\section{Acknowledgements}

The authors would like to thank the MCC patients and families for entrusting us with their care. We are also greatly appreciative of the compassionate care and endless dedication of our MCC clinical care team at the Seattle Cancer Care Alliance, including pharmacy staff (especially Michelle Lentz and Pharm C team providers), nurses, and treatment coordinators.

\section{Conflicts of interest}

Paul Nghiem: Paid consultant (EMD-Serono); Shailender Bhatia: Advisory board (Genentech; EMD-Serono); Research support (EMD-Serono, BMS, Merck, Oncosec, Immune Design, NantKwest).

10. Nghiem PT, Bhatia S, Lipson EJ et al: PD-1 blockade with pembrolizumab in advanced Merkel-cell carcinoma. N Engl J Med, 2016; 374: 2542-52

11. D’Angelo SP, Russell J, Hassel JC et al: First-line (1L) avelumab treatment in patients (pts) with metastatic Merkel cell carcinoma (mMCC): Preliminary data from an ongoing study. J Clin Oncol, 2017; 35: 9530

12. Topalian SL, Bhatia S, Hollebecque A et al: Abstract CT074: Non-comparative, open-label, multiple cohort, phase $1 / 2$ study to evaluate nivolumab (NIVO) in patients with virus-associated tumors (CheckMate 358): Efficacy and safety in Merkel cell carcinoma (MCC). Cancer Res, 2017; 77: CT074-CT

13. Kaufman HL, Russell J, Hamid O et al: Avelumab in patients with chemotherapy-refractory metastatic Merkel cell carcinoma: A multicentre, singlegroup, open-label, phase 2 trial. Lancet Oncol, 2016; 17: 1374-85

14. Bhatia S, Afanasiev O, Nghiem P: Immunobiology of Merkel cell carcinoma: Implications for immunotherapy of a polyomavirus-associated cancer. Curr Oncol Rep, 2011; 13: 488-97

15. Vazmitel M, Michal M, Shelekhova KV et al: Vascular changes in merkel cell carcinoma based on a histopathological study of 92 cases. Am J Dermatopathol, 2008; 30: 106-11

16. Brunner M, Thurnher D, Pammer J et al: Expression of VEGF-A/C, VEGF-R2, PDGF-alpha/beta, c-kit, EGFR, Her-2/Neu, Mcl-1 and Bmi-1 in Merkel cell carcinoma. Mod Pathol, 2008; 21: 876-84

17. Swick BL, Srikantha R, Messingham KN: Specific analysis of KIT and PDGFRalpha expression and mutational status in Merkel cell carcinoma. J Cutan Pathol, 2013; 40: 623-30 
18. Kartha RV, Sundram UN: Silent mutations in KIT and PDGFRA and coexpression of receptors with SCF and PDGFA in Merkel cell carcinoma: Implications for tyrosine kinase-based tumorigenesis. Mod Pathol, 2008; 21: 96-104

19. Feinmesser M, Halpern M, Kaganovsky E et al: c-kit expression in primary and metastatic merkel cell carcinoma. Am J Dermatopathol, 2004; 26 458-62

20. Llombart B, Monteagudo C, Lopez-Guerrero JA et al: Clinicopathological and immunohistochemical analysis of 20 cases of Merkel cell carcinoma in search of prognostic markers. Histopathology, 2005; 46: 622-34

21. Strong S, Shalders K, Carr R, Snead DR: KIT receptor (CD117) expression in Merkel cell carcinoma. Br J Dermatol, 2004;150: 384-85

22. Su LD, Fullen DR, Lowe L et al: CD117 (KIT receptor) expression in Merkel cell carcinoma. Am J Dermatopathol, 2002; 24: 289-93

23. Kukko $H$, Koljonen V, Lassus $P$ et al: Expression of vascular endothelial growth factor receptor-2 in Merkel cell carcinoma. Anticancer Res, 2007; 27: $2587-89$

24. Davids MS, Charlton A, Ng SS et al: Response to a novel multitargeted tyrosine kinase inhibitor pazopanib in metastatic Merkel cell carcinoma. Clin Oncol, 2009; 27: e97-100

25. Nathan PD, Gaunt P, Wheatley K et al: UKMCC-01: A phase II study of pazopanib (PAZ) in metastatic Merkel cell carcinoma. J Clin Oncol, 2016; 34: 9542
26. Elshabrawy HA, Chen Z, Volin MV et al: The pathogenic role of angiogenesis in rheumatoid arthritis. Angiogenesis, 2015; 18: 433-48

27. Paulson KG, lyer JG, Blom A et al: Systemic immune suppression predicts diminished Merkel cell carcinoma-specific survival independent of stage. J Invest Dermatol, 2013; 133: 642-46

28. Hu C, Jiang $X$ : The effect of anti-angiogenic drugs on regulatory $T$ cells in the tumor microenvironment. Biomed Pharmacother, 2017; 88: 134-37

29. Finke JH, Rini B, Ireland J et al: Sunitinib reverses type-1 immune suppression and decreases T-regulatory cells in renal cell carcinoma patients. Clin Cancer Res, 2008; 14: 6674-82

30. Gardair C, Samimi M, Touze A et al: Somatostatin receptors $2 A$ and 5 are expressed in Merkel cell carcinoma with no association with disease severity. Neuroendocrinology, 2015; 101: 223-35

31. Iyer JG, Parvathaneni U, Gooley T et al: Single-fraction radiation therapy in patients with metastatic Merkel cell carcinoma. Cancer Med, 2015; 4 1161-70

32. Schutz FA, Je Y, Richards CJ, Choueiri TK: Meta-analysis of randomized controlled trials for the incidence and risk of treatment-related mortality in patients with cancer treated with vascular endothelial growth factor tyrosine kinase inhibitors. J Clin Oncol, 2012; 30: 871-77

33. Kawasaki K, Hamamoto Y, Fukada J et al: Fatal hemorrhage in a patient with advanced soft tissue sarcoma following radiation and pazopanib treatment: A case report. Oncol Lett, 2016; 11: 2408-10 